\title{
RE-ORIENTASI KETERAMPILAN KERJA LULUSAN PENDIDIKAN KEJURUAN
}

\author{
Ivan Hanafi \\ Fakultas Teknik - Universitas Negeri Jakarta \\ E-mail: hanafi@yahoo.com
}

\begin{abstract}
Abstrak: Skills Re-orientation for Vocational School Graduates. Pendidikan kejuruan diyakini memiliki konstribusi yang besar bagi perkembangan masyarakat dan peningkatan ekonomi suatu negara. Daya saing negara bergantung banyak pada tenaga kerja yang memilik pengetahuan dan keterampilan, karena mereka akan meningkatkan efisiensi dan nilai tambah produksi. Pendidikan dan latihan kejuruan pada hakekat adalah sebagai tempat untuk menyiapkan tenaga kerja berpengetahuan, berketerampilan, dan berkepribadian bagi memenuhi harapan dunia kerja dan industri. Tetapi kondisi riil menunjukkan banyak lulusan pendidikan kejuruan yang tidak memperoleh kerja, bahkan mereka yang telah bekerjapun menghadapi masalah keterampilan. Bekal pengetahuan dan keterampilan yang mereka miliki tidak cukup untuk dapat sustain dalam lingkungan kerja. Hal itu salah satunya disebabkan karena tenaga kerja tidak memiliki employability skills yang cukup seperti permintaan dunia kerja. Untuk itu, lembaga pendidikan kejuruan diharapkan mengantisipasi dengan tepat perkembangan yang terjadi di dunia kerja melalui berbagai pendekatan pembelajaran agar lebih fleksibel untuk merespon permintaan dunia kerja yang berubah dengan cepat.
\end{abstract}

Kata kunci: lulusan, pendidikan kejuruan

\section{RE-ORIENTASI KETERAMPILAN KERJA LULUSAN PENDIDIKAN KEJURUAN}

\begin{abstract}
Skills Re-orientation for Vocational School Graduates. It is believed that vocational education makes particular contribution on Indonesian concerning economics development. A competitiveness of the nation depends on quality of human resource in term of knowledge, skills, attitude. Vocational education and training basically is provided for preparing youth to have knowledge, skills, and characteristics to meet the requirements of work place. However, in fact Vocational High School leavers are unemployed, and the employed even face skills problems. Their knowledges, skills, and attitudes are under standard of work place requirements and incapable of sustaining hie/her current position in the work place. One of the reasons is because they don't have enough employability skills to fulfil work place requirements. Therefore, vocational training institutions are required to anticipate firmly to developing the work place by employing learning strategies in order to have flexibilty due to a rapid changing of work place requirements.
\end{abstract}

Keywords: graduate, vocational education

\section{PENDAHULUAN}

Pendidikan kejuruan diyakini sebagai bagian yang tidak terpisahkan perkembangan masyarakat, dan bahkan besar konstribusinya bagi peningkatan ekonomi suatu negara. Carr dan Hartnett (2002) mengatakan "the paradigm of vocational education is economic: to contribute to the regeneration and modernization of industry and so advance the economic development and growth of modern society." Daya saing negara tergantung pada pengetahuan dan keterampilan tenaga kerjanya dan untuk membuat tenaga kerja berpengetahuan dan berketerampilan, banyak bergantung pada kualitas pendidikannya. Tenaga kerja yang terlatih akan dapat meningkatkan nilai tambah produksi berupa produktivitas yang tinggi, biaya rendah, tingginya kualitas produksi, dan pada 
akhirnya investasi yang ditanam dapat kembali dengan lebih cepat.

Para ahli lain berpendapat bahwa pendidikan kejuruan merupakan faktor kunci dalam perkembangan ekonomi, persaingan dan bahkan stabilitas sosial pada banyak negara, termasuk negara maju. Wilkins (2001) menyatakan "vocational education is one of key factors in ensuring economic development, competitiveness and social stability in all countries, both developing and industrialized." Hal itu disebabkan pada suatu keyakinan bahwa keberhasilan pendidikan kejuruan dalam menghasilkan tenaga kerja terampil merupakan bagian penting bagi strategi pengembangan sumberdaya manusia untuk memberi bekal masyarakat dengan pengetahuan dan keterampilan yang diperlukan dunia kerja dan industri.

Pendidikan kejuruan mengalami perkembangan dari waktu ke waktu mengikuti perubahan dunia kerja. Namun demikian, tidak mengubah hakekatnya sebagai salah satu tempat penyiapan tenaga kerja yang diharapkan memiliki serangkaian pengetahuan, keterampilan, dan juga kepribadian yang baik untuk memenuhi harapan dunia kerja dan industri. Disamping itu, para lulusan pendidikan kejuruan diharapkan dapat mengisi kesempatan pekerjaan yang tersedia dengan bekal yang dimilikinya dan mendapatkan imbalan yang sesuai. Tetapi kondisi saat ini sangat berbeda dan tidak seperti yang diharapkan. Banyak lulusan pendidikan kejuruan yang tidak memperoleh kerja atau menganggur, bahkan mereka yang telah bekerjapun bukan tanpa masalah. Bekal pengetahuan dan keterampilan yang mereka miliki tidak cukup untuk dapat bertahan (sustain) dalam lingkungan kerja. Banyak faktor yang diduga sebagai penyebabnya, antara lain dari sisi penyedia tenaga kerja (pendidikan), dari sisi peminta (industri), dan juga dari sisi para lulusan itu sendiri. Sejumlah faktor yang diidentifikasi menjadi masalah tidak sustain-nya para lulusan pendidikan kejuruan saat ini antara lain (1) informasi yang diperoleh tidak cukup mendukung memperoleh pekerjaan; (2) industri pada umumnya mencari tenaga kerja yang berpengalaman; (3) keluhan pihak industri bahwa kebanyakan para lulusan tidak mempunyai keterampilan yang diharapkan oleh industri, terutama employabilitas untuk dapat survive dan bertahan pada berbagai situasi dan kondisi kerja.

Dari beberapa faktor yang diidentifikasi menjadi hambatan tidak terpenuhinya tuntutan dunia kerja dan industri terhadap lulusan pendidikan kejuruan, salah satunya adalah adanya mismatch of skill required by workforce. Kebutuhan dunia kerja terhadap keterampilan yang dimiliki lulusan pendidikan kejuruan memiliki implikasi terhadap kurikulum, seperti yang diletakkan pada judul tulisan ini. Terlepas dari berbagai kepentingan di luar konteks proses seleksi tenaga kerja baru, makalah ini akan membahas keterkaitan keterampilan yang diharapkan oleh dunia kerja dan industri dan memenuhi tuntutan keterampilan lulusan untuk menyelesaikan bidang pekerjaan kejuruan di era persaingan dan globalisasi saat ini. Strategi dan pendekatan seperti apa yang tepat dan sesuai bagi pendidikan kejuruan sebagai bagian sistem pendidikan untuk menyiapkan tenaga kerja yang berpengetahuan dan berketerampilan untuk dapat memenuhi tuntutan dunia kerja dan 
industri, baik pada tingkat pendidikan menengah dan pendidikan tinggi?

\section{PEMBAHASAN}

\section{Tuntutan Keterampilan di Dunia Kerja}

Karakteristik iklim bekerja selalu berubah dengan cepat, seiring dengan kemajuan dan perkembangan teknologi saat ini. Mesin robot telah mendominasi industri, baik industri pembuatan maupun industri perakitan. Berbagai peralatan otomatis dengan otak mikroprosesor yang pintar, makin banyak terlihat di ruangruang industri. Demikian pula dengan komputer di kantor, pabrik, maupun di rumah. Komputer bukan lagi merupakan barang yang istimewa, karena dewasa ini, komputer dengan berbagai macam piranti lunaknya 'hanyalah' merupakan alat bantu yang harus tersedia untuk menyelesaikan tugas yang banyak.

Untuk itu, tuntutan terhadap keterampilan yang dimiliki oleh tenaga kerja juga mengalami perubahan. Mereka tidak hanya dituntut untuk mengetahui dengan baik bidang-bidang yang ditekuninya, tetapi juga harus memiliki keterampilan yang dapat mempertahankan keberlangsungan pekerjaan dengan kondisi yang lebih baik. Sebagai contoh, seorang lulusan pendidikan dan latihan kejuruan, siapapun dia dan bekerja dalam bidang apapun, tuntutan terhadap keterampilan menggunakan komputer merupakan hal yang mutlak harus dimiliki. Sebut saja keterampilan itu adalah basic skills yang tidak boleh tidak harus dimiliki oleh lulusan pendidikan kejuruan. Setidaknya lulusan dapat menggunakan program aplikasi kantor, seperti pemrosesan kata dan spreadsheet. Apalagi jika tuntutan terhadap pekerjaan menghendaki seseorang dapat menyusun dan membuat program, maka ia harus dapat menyusun struktur logika pemrograman untuk menjalankan peralatan yang menjadi objek pekerjaanya.

Selain tuntutan basic skills dan juga technical skills atau keterampilan dalam bidang yang ditekuni, dunia kerja dan industri menuntut adanya keterampilan employabilitas atau generic skills yang harus dimiliki oleh seorang calon tenaga kerja sesuai dengan karakteristik iklim kerja saat ini. Keterampilan employabilitas secara khusus terkait dengan kemampuan bekerja seseorang dengan berbagai situasi dan memiliki kemampuan berfikir kritis, berkomunikasi secara efektif, dan memiliki kekuatan dan semangat untuk terus belajar dan bekerja. York \& Knight mengatakan bahwa keterampilan employabilitas adalah are skills needed to raise a worker's effectiveness and improve his work abilities across all occupations (York \& Knight, 2004)

Keterampilan employabilitas dinilai sangat penting, karena karakteristik pekerjaan saat ini menuntut adanya inisiatif, fleksibilitas, dan kemampuan seseorang untuk menangani tugastugas yang berbeda. Hal itu berarti keterampilan yang dimiliki oleh seseorang tenaga kerja tidak harus spesifik, tetapi seyogyanya lebih berorientasi pada layanan dan lebih penting lagi memiliki keterampilan sosial yang tinggi. Keterampilan employabilitas termasuk (1) keterampilan dasar yang meliputi membaca, menulis dan berhitung; (2) keterampilan interpersonal termasuk berkomunikasi dan bekerja dalam tim; dan (3) atribut diri, diantaranya kemampuan belajar dan bagaimana menghadapi perubahan yang selalu terjadi di masyarakat (ANTA, 2003). 
Hal itu memberikan gambaran yang makin jelas bahwa pengetahuan dan keterampilan yang diperlukan oleh dunia usaha dan industri tidak hanya bersandar kepada keterampilan kerja yang sesuai dengan bidang keahlian yang diminta, tetapi juga diperlukan keterampilan employabilitas (employability skills) termasuk di dalamnya adalah kualitas individu (personal qualities). Lankard (1990) berdasarkan hasil kajiannya, mengidentifikasi bahwa pada saat ini, terdapat lima keterampilan yang diperlukan oleh dunia kerja dan industri dan harus dimiliki oleh seseorang karyawan agar dapat bekerja dan mencapai sukses. Keterampilan yang dimaksud adalah basic academic skills (komunikasi, matematika, dan sains) dan keterampilan bidang kejuruan yang sesuai dengan pekerjaan (occupational skills). Namun keterampilan tersebut masih mengandung resiko dan kritis untuk dapat meningkatkan karir, terutama tidak menjamin untuk menjadi sukses dalam meniti pekerjaan. Berdasarkan hasil kajiannya, Lankard menyampaikan bahwa para employers yakin bahwa employability skills - keterampilan yang dapat menjadikan seseorang bertahan dan dapat mengikuti perubahan-perubahan penting dalam pekerjaan dan kehidupannya. Keterampilan tersebut seharusnya dimiliki oleh lulusan pendidikan kejuruan untuk cepat menyesuaikan diri dengan berbagai situasi kerja.

Sebenarnya hal itu sudah lama dijadikan sebagai dasar bagi proses seleksi calon tenaga kerja. Pada tahun 1986, gabungan industriawan Inggris misalnya, telah menempatkan kualitas individu sebagai salah satu komponen penting yang diperhatikan untuk menempatkan seseorang pada jabatan tertentu. Karena mereka berpendapat bahwa seorang yang memiliki kemampuan akademik sangat baik, belum menjamin dapat bekerja dengan baik dan belum tentu dapat beradaptasi dan mengikuti perkembangan dunia kerja dengan cepat. Untuk itu, seorang karyawan setidaknya memiliki kemampuan berkomunikasi, baik dalam bentuk lisan maupun tulisan, motivasi tinggi, potensi memimpin, pandangan yang luas dan sikap positif terhadap perubahan, serta memiliki kemampuan dasar matematika yang baik (Lauglo dan Lillis, 1988).

Imel (1989) merangkum dalam hasil kajiannya bahwa walaupun para majikan mengharuskan seseorang memiliki keterampilan khusus dalam bidang pekerjaan tertentu, tetapi mereka menuntut pekerja memiliki keterampilan akademik dan keterampilan employabilitas lain, diantaranya membaca, menulis, dan berhitung; keterampilan komunikasi, baik lisan maupun tulisan; kemampuan mengatasi masalah (problem-solving ability); keterampilan kemampuan bekerja (employability skills); keterampilan reasoning; keterampilan kepemimpinan; keterampilan interpersonal; keterampilan belajar (learning-how-to-learn); dan keterampilan bekerjasama dalam tim (teamwork skills).

Amerika telah pula memberikan perhatian terhadap perkembangan kualitas dan keterampilan yang diperlukan untuk meningkatkan daya saing produksi negara tersebutmelalui the Secretary's Commission on Achieving Necessary Skills (SCANS). Pada awalnya, SCANS menemukan tujuh keterampilan fungsional, yaitu keterampilan dalam hal resource management, information management, social interaction, systems behaviour and performance, human and 
technology interaction, and affectifve skills. Berdasarkan review dan verifikasi yang mendalam dan diperbaharui, SCANS membuat dua kelompok keterampilan dan kompetensi yang harus dimiliki oleh karyawan, yaitu foundation skills terdiri dari basic skills, thinking skills, dan personal qualities serta workplace competencies, yang terdiri dari resources, interpersonal, information systems, dan technology.

Kajian terhadap employability skills juga dilakukan di Australia pada tahun 2002 oleh kamar dagang dan industri Australia dengan melibatkan sejumlah industri, lembaga swasta dan pemerintah, termasuk departemen pendidikan, sains, dan latihan. Tujuan kajian tersebut untuk mengidentifikasi keterampilan individu yang harus dimiliki oleh calon tenaga kerja untuk memasuki dunia kerja dan bagaimana karyawan yang telah bekerja dapat berpartisipasi aktif untuk meningkatkan kinerja perusahaan. Hasil kajian mengidentifikasi dua hal sangat penting, yaitu (1) faktor yang menentukan menghadapi perubahan dunia kerja; dan (2) employability skills untuk masa depan (McLeish, 2002).

Hasil kajian pertama mengidentifikasi adanya enam hal penting yang berdampak kepada tuntutan keterampilan karyawan, yaitu (1) layanan berbasis pelanggan; (2) peran teknologi; (3) persyaratan perudangan dan financial; (4) pendekatan belajar dan latihan; (5) penekanan pada inovasi; dan (6) peningkatan kerja berbasis proyek. Sementara hasil kajian kedua mengisyaratkan adanya perubahan permintaan dunia kerja terhadap keterampilan yang dimiliki oleh karyawan, yaitu lebih menekankan kepemilikan employability skills dibandingkakan dengan industry specific skills. Bagian yang dianggap mendasar dan penting diantaranya pekerja memiliki kualitas individu yang tinggi, seperti kejujuran, percaya diri, dan penampilan diri. Para industriawan melihat bahwa nilai atau kualitas individu yang dimiliki karyawan sangat mendukung keharmonisan di tempat kerja dan membantu karyawan dalam menghadapi setiap perubahan.

Dalam kerangka keterampilan tersebut, diidentifikasi sejumlah perangkat keterampilan yang diperlukan, baik untuk keterampilan kualitas/nilai individu dan employability skills yang seharusnya dimiliki oleh seseorang karyawan. Keterampilan yang dipaparkan merupakan urutan peringkat berdasarkan kepada jumlah jawaban yang diberikan oleh responden dari dunia usaha dan industri kecil dan menengah di Australia. communication dan teamwork mendapat peringkat tertinggi, selain kualitas individu personal values yang diperlukan oleh dunia usaha dan industri saat ini. Sementara keterampilan teknikal, tetap diperlukan dan berimbang untuk berbagai tingkatan dan posisi pekerjaan.

Untuk menjalin hubungan yang lebih erat antara dunia kerja dan industri dengan dunia pendidikan, pada tahun 1992 The Conference Board of Canada, juga telah mengembangkan profil employability skills sebagai alat untuk membantu para pendidik dalam rangka menyiapkan lulusannya memasuki dunia kerja. Profil tersebut, diperbaharui pada bulan Mei 2000 - sebagai refleksi terhadap tuntutan pekerjaan di era globalisasi - yang kemudian dikenal dengan istilah Employability Skills 2000+. Kerangkanya terdiri dari employability skills, attitudes dan behaviour. Hal itu 
merupakan hasil kajian dan pengembangan yang dilakukan oleh forum gabungan antara pebisnis, industriwan, dan pendidik.

Kajian literatur singkat yang dilakukan terhadap iklan permintaan karyawan baru dan persyaratannya pada koran harian The New Straits Times - Malaysia, juga menunjukkan hal yang sama. Permintaan karyawan baru oleh dunia usaha dan Industri di Malaysia berturutturut sebagai berikut (1) keterampilan komunikasi; (2) keterampilan interpersonal; (3) menguasai komputer; (4) kerjasama dalam tim; (5) independen; (6) potensi kepemimpinan; (7) berfikir logis; dan (8) motivasi diri, jujur, dan komitmen yang tinggi (Bakar dan Hanafi, 2004).

Hal itu menunjukkan, bahwa di berbagai belahan dunia manapun, sekarang ini permintaan terhadap keterampilan karyawan mulai menunjukkan adanya pergeseran permintaan. Tuntutan terhadap sikap karyawan makin menjadi prioritas, bukan hanya sekedar terampil dalam bidang pekerjaan, tetapi juga memiliki sikap positif untuk bisa bekerja dengan baik dan meningkat dari waktu ke waktu. Permintaan dunia usaha dan industri mengalami perubahan dengan telah dimulainya era globalisasi. Hal itu mungkin disebabkan persaingan yang ketat, sehingga setiap langkah perusahaan harus selalu diperhitungkan dan setiap karyawan harus memahami hal ini, agar dapat turut serta berpartisipasi memajukan perusahaan bersamasama.

\section{Implikasi pada Pendidikan Kejuruan}

Dari berbagai kajian sebelumnya, nampak bahwa dunia kerja dan industri memerlukan seperangkat keterampilan employabilitas (employability skills) yang seharusnya dimiliki oleh karyawan pada setiap jenjang dan tingkat pekerjaan, selalin keterampilan teknikal yang sesuai dengan bidang pekerjaannya. Hal itu menunjukkan bahwa saat ini terjadi perubahan terhadap permintaan tenaga kerja oleh dunia kerja dan industri, yakni mengharuskan seorang lulusan pendidikan kejuruan untuk memiliki keterampilan employabilitas bersama-sama dengan keterampilan teknikal. Untuk itu, agar tidak terjadi mismatch antara permintaan dunia kerja dan penyiapan tenaga terampil dalam berbagai bidang kejuruan, maka sekolah maupun lembaga pendidikan kejuruan yang lebih tinggi sebagai lembaga penyedia tenaga kerja yang siap bekerja dalam dunia yang berubah seperti saat ini, selayaknya memperhatikan dan menindaklanjuti perubahan ini.

Perubahan yang terjadi di tempat kerja, seyogyanya mendapat tanggapan dengan tepat dan sesuai dari lembaga penghasil tenaga kerja, seperti halnya pendidikan kejuruan. Keterlambatan menanggapi permintaan perubahan tuntutan pasar kerja akan berakibat kurang baik terhadap kepentingan masyarakat dan yang pasti dapat memperlebar jurang antara penyediaan tenaga kerja yang berpengetahuan dan berketerampilan di satu sisi dengan dunia kerja dan industri di sisi lain. Di samping itu, jika masalah ini (mismatch skills requirement) tidak diatasi dengan tepat, maka dapat berakibat lebih jauh kepada rendahnya daya saing kualitas yang dihasilkan dunia kerja dalam menghadapi tantangan global.

Dalam sistem pendidikan, maka tentu banyak hal yang harus disesuaikan (baca: diubah) untuk dapat merespon perubahan tersebut dengan tepat dan mengena pada sasaran. Salah satu komponen input yang 
penting dan paling mungkin untuk disesuaikan adalah kurikulum. Untuk itu, salah satu cara adalah dengan merombak kurikulum yang digunakan atau setidaknya menjadikan permintaan dunia usaha dan industri tersebut sebagai sandaran bagi lembaga pendidikan kejuruan untuk melakukan pengembangan kurikulum yang dimiliki saat ini. Walaupun demikian, tentu tidak akan langsung menjadi obat mujarab bagi terbinanya sistem dengan sempurna dengan menjamin para lulusan dapat bekerja langsung dan meniti karir dengan baik. Namun, setidaknya ada upaya merespon dari lembaga penyedia tenaga kerja terhadap perubahan dan perkembangan yang terjadi di dunia kerja.

Disamping itu, tentu saja perubahan demi perubahan harus pula dilakukan terhadap semua komponen input, termasuk perubahan sikap semua jajaran yang ada dan terlibaht pada lembaga pendidikan kejuruan. Hal itu yang biasanya sulit dilakukan secara cepat. Menurut para ahli, perubahan yang harus dilakukan terdiri atas dua tingkatan. Pertama first order change atau perubahan secara infra struktur atau fisik, termasuk perubahan kurikulum dan perubahan fasilitas sebagai input dalam sistem pendidikan. Perubahan itu dapat mudah dilakukan bila telah ada kesepakatan bersama dan tersedia dukungan finansial yang cukup. Kedua second order change atau perubahan mindset dan sikap para pelaku dalam system pendidikan. Perubahan tingkat kedua ini tidak mudah dilakukan, karena menyangkut banyak hal termasuk latar belakang sosial orang-orang di dalamnya. Namun demikian, perubahan apapun, apabila tidak diikuti oleh berubahnya mindset para pelaku, maka pada hakekatnya tidak terjadi perubahan.

Jika lembaga pendidikan kejuruan ingin lebih dipercaya dan tidak tertinggal, atau bahkan ditinggalkan oleh para pengguna jasanya maka seharusnya melakukan berbagai perubahan yang perlu dengan didasari perkembangan dunia kerja. Hal itu dapat dilakukan, selama semua orang yang terlibat dalam sistem pendidikan, mendukung adanya perubahan dan tentu dengan didasari oleh pemahaman secara menyeluruh terhadap permintaan pasar yang berubah dan terjadi di dunia 'luar' pendidikan. Perubahan permintaan terhadap keterampilan adalah hak dunia luar, yang seharusnya dapat dipahami dan direspon dengan tepat oleh lembaga pendidikan sebagai tempat persiapan penyediaan tenaga kerja. Sebagai contoh, permintaan terhadap seorang calon karyawan yang harus memiliki keterampilan komunikasi yang baik, lisan maupun tulisan. Hal itu tentu harus disikapi dengan mengkaji pendekatan pembelajrannya. Salah satu adalah dengan menggunakan pendekatan learning by project based yang didukung pemaparan dalam sidang kecil pada setiap akhir kegiatan atau setiap akhir proyek. Dengan demikian, diharapkan peserta didik terbiasa melakukan komunikasi untuk menyampaikan hasil-hasil yang telah diperolehnya dan yang lebih penting lagi adalah mempertahankan ide dan pendapatnya dengan didasari teori yang kokoh dan pengalaman praktisnya.

Saat ini, tuntutan agar seorang karyawan dapat bekerjasama dalam tim atau memiliki integritas diri dalam melakukan setiap pekerjaan, merupakan hal yang mutlak. Untuk itu, lembaga pendidikan perlu melakukan kajian 
yang mendalam agar menemukan bentuk pendekatan pembelajaran yang tepat untuk mendukung penguatan pada materi kerjasama dan membangun integritas dalam satu tim kerja, sehingga terbentuk sikap dan komitmen yang tinggi sebagai anggota tim dan terbiasa melakukan berbagai pekerjaan secara bersama dengan tugas dan tanggungjawab sesuai perannya. Begitu pula untuk jenis keterampilan lain yang memerlukan adanya pengkajian yang terus menerus untuk memperbaiki dan meningkatkan kesesuaian permintaan dunia kerja melalui pendekatan pembelajaran yang sesuai.

\section{PENUTUP}

Beberapa hal yang menyebabkan adanya mismatch yang berkepanjangan, antara lain pendidikan kejuruan tidak cukup fleksibel dalam merespon permintaan dunia kerja dan industri, terutama terkait dengan perubahan sikap dan keterampilan kerja yang dituntut dunia kerja. Sejatinya, permintaan dan tuntutan terhadap keterampilan yang dimiliki tenaga kerja bukanlah hal baru. Sejak lebih dari satu decade hal itu di bincangkan oleh kalangan dunia kerja dan industri. Namun baru beberapa tahun terakhir kembali ramai dibincangkan tentang perlunya para pekerja memiliki employability skills dengan berbagai derivasinya.

Kemunculan kembali kriteria keterampilan yang harus dimiliki oleh seorang pekerja, diduga karena memang belum terpenuhinya permintaan dunia kerja terhadap keterampilan yang dimiliki tenaga kerja, khususnya lulusan dari pendidikan kejuruan. Namun demikian, tuntutan keterampilan yang dominan saat ini, telah bergeser kepada keterampilan yang cenderung kepada domain sikap dan integritas pekerja. Hal itu seperti yang pernah disampaikan Lankard (1990) bahwa keterampilan dasar akademik dan keterampilan pekerjaan tidak dapat menjamin seseorang bekerja dengan baik dan mampu secara terus menerus mengikuti perubahan yang berkembang dinamis dari waktu ke waktu di dunia kerja. Untuk itu, seorang pekerja seharusnya memiliki employability skills untuk dapat menjamin bertahan mengikuti perubahan dan dinamika dunia kerja.

Beberapa negara maju telah melakukan kajian mendalam terhadap adanya permintaan keterampilan employability yang harus dimiliki oleh calon pekerja ataupun pekerja. Hal yang menarik adalah bahwa hampir semua kajian yang merekomendasi keterampilan employability dilakukan oleh lembaga nonpendidikan, seperti SCANS di koordinasi kementerian tenaga kerja Amerika Serikat, ACCI/BCA merupakan kamar dagang dan industri di Australia, dan the Conference Board of Canada yang lebih merupakan kumpulan bisnis dan industri di negara Kanada. Hasil-hasil kajian tersebut diyakini lebih objektif, karena terlepas dari unsur tekanan ataupun kepentingan lembaga pendidikan. Untuk itu, lembaga pendidikan kejuruan seharusnya juga responsif terhadap perkembangan tersebut. Pengembangan kurikulum dan pendekatan pembelajaran yang berorientasi perkembangan dunia kerja dengan diikuti perubahan strategi pembelajaran sudah sepatutnya menjadi pertimbangan kuat lembaga pendidikan kejuruan untuk dilaksanakan secara bijaksana. Dunia 'luar' telah berubah dengan sangat cepat dan telah pula menuntut keterampilan employability yang harus dimiliki oleh peserta didik, agar kelak ketika bekerja 
mereka dapat benar-benar berpartisipasi aktif untuk meningkatkan kualitas dan performance dunia kerja dan industri yang pada akhirnya akan dapat menyumbang secara langsung ataupun tidak langsung kepada peningkatan ekonomi negara.

\section{DAFTAR PUSTAKA}

Australian National Training Authority ANTA. (2003). Defining Generic Skills. At a Glance. http://www. ncver.edu.au. Diakses pada 16 Feb, 2004.

Imel, Susan. (1989). Employers' Expectations of Vocational Education. ERIC Clearinghouse on Adult Career and Vocational Education Columbus $\mathrm{OH}$. http://www.ericfacility.net/ericdigests/e d312454.html. Feb 20, 2004.

Kane, Michael. (1990). The Secretary's Commission on Achieving Necessary Skills (SCANS): Identifying and Describing The Skills Required by
Work. Washington, D.C.: Pelavin Associates, Inc.

Lankard, Bettina A. (1990). Employability--The Fifth Basic Skill. ERIC Clearinghouse on Adult Career and Vocational Education Columbus $\mathrm{OH}$. http://SearchERIC.org/digests/ed325659 .html. Feb 16, 2004.

Leish Mc, Anne. (2002). Employability Skills for Australian Small and Mediaum Sized Enterprises:Report of the interviews and focus groups with small and medium enterprises. Departement of Education, Sicence and Training.

The Conference Board of Canada. (2000). Employability Skills 2000+. Ottawa.

http://www.conferenceboard.ca/nbec. Accessed on Feb 27, 2004.

Wilkins, Stephen. (2001). Human Resource Development through Vocational Education in the United Arab Emirates: the case of Dubai Polytechnic. Journal of Vocational and Technical Education and Training. Vol. 54 Number 1. 
